\title{
Sustainable Development: A Review of Theoretical Contributions
}

\section{Tuazon ${ }^{\mathrm{a}^{*}}$, G.D. Corder ${ }^{\mathrm{a}}$, B.C. McLellan ${ }^{\mathrm{b}}$}

${ }^{a}$ The University of Queensland, Sustainable Minerals Institute, Centre for Social Responsibility in Mining, St Lucia QLD 4072, Australia

${ }^{b}$ Graduate School of Energy Science, Kyoto University, Yoshidahonmachi, Sakyo-ku, Kyoto 6o6-8501, Japan.

Received: May 24, 2013/ Accepted: May 28, 2013

\section{Abstract}

This paper reviews the historical, conceptual and operational development of the field of sustainability from a theoretical and practical perspective. It discusses the advantages and disadvantages, omissions and additions to various sustainability approaches. These sustainability elements are combined in a hierarchical framework to enable a clearer understanding of the interrelations between the various definitional elements.

Despite the mature state of developed concepts and definitions for sustainability, the multi-faceted nature of sustainability ensures that a judicious understanding of the various sustainability definitions and structures is crucial when applying or integrating sustainability in business or operational decision-making processes.

Keywords:sustainability; sustainable development; history; frameworks; indicators.

Abbreviations:
\begin{tabular}{|lrl|}
\hline GRI & $:$ & Global Reporting Initiative \\
LCA & $:$ & Life Cycle Assessment \\
MMSD $:$ & Mining, Minerals and Sustainable Development \\
UNCHE $:$ & United Nations Conference on the Human \\
& Environment \\
WCED $\quad$ United Nations) World Commission on the & Environment and Development \\
&
\end{tabular}

\section{Introduction}

This paper is the product of a wide-ranging review of sustainability concepts, principles and frameworks, originally with a focus on operationalising sustainability for the minerals industry [1]. The review has been supplemented and revised to provide a succinct commentary on the current methods of understanding, framing and measuring sustainability.

${ }^{*}$ Corresponding Author

Tel.: +61 421464 915; E-mail: d.tuazon@uq.edu.au

\subsection{History of sustainability}

Sustainability has only been recognised formally as a concept within the last half-century, with developments in contributions towards understanding the topic accelerating mainly from the late 1970s. On the other hand, examples of unsustainability are apparent in history which dates back as far as 400 to 800 C.E. where resource overuse, uncontrolled materialism and overpopulation contributed to the ultimate downfall of the inhabitants of Easter Island (Rapa Nui) [2]; these concepts and others are recognised now as being embodied in some form in the idea of sustainability.

The first commonly recognised contribution of sustainability was the apparent danger of overpopulation. Thomas Malthus, an English parson, published his Essay on Population in the late $18^{\text {th }}$ century, detailing that the world would run into serious problems stemming from the exponential growth of the population but a mere arithmetic growth in available food supply [3]. Despite Malthus's argument being denounced at the time, the ideas of resource scarcity and environmental sensitivity began to materialise as a result of global changes arising from the Industrial Revolution and world wars. After the second world war had ended, environmental awareness came to a head in 1962 when scientist Rachel Carson published Silent Spring, a book which detailed the destruction of bird life due to the widespread use of DDT [2, 3]. Although Carson was widely criticised for her supposed unrealistic scenarios and unjust scaremongering, Silent Spring is often credited with beginning the environmentalist movement as the effects of uncontrolled use of technology and human activity on the functioning of the environment began to be recognised [3-5].

In the years following Silent Spring, new concepts that contributed to the modern understanding of sustainability began to take shape. Paul Ehrlich partially revived the Malthusian idea of overpopulation and attempted to bring the perspectives of affluence and technology into the ultimate determination of human impact on the environment $[3,6-8]$. The Club of Rome, a non-profit organisation, undertook a study that attempted to model the entire world and its processes and understand the dynamics related to population, resource availability (including non-renewables, such as oil), access to food and other natural dynamics. The results of the study were published in 1972 and, in similar fashion to Carson's Silent Spring, became the centrepiece of criticism, mainly amongst the global industrial community due to unrealistic assumptions and apparent 'scare' scenarios related to resource scarcity [3, 4, 9-11].

The United Nations (UN) began to recognise sustainability and environmental awareness as a global issue through the Stockholm convention of $1972[12,13]$. Although the convention was important in laying the groundwork for further understanding sustainability, certainly one of the most recognised and oft quoted marks in history related to sustainability was the 1987 UN World Commission on the Environment and Development (WCED). The first formalised definition of sustainability came out of the report of the WCED, Our Common Future[3]. The chair of the WCED at the time was Norwegian Labour Party leader Gro Harlem Brundtland, hence the report's definition of sustainability is commonly known as the "Brundtland definition": "Sustainable development is development that meets the needs of the present without compromising the ability of future generations to meet their own needs"[14].

Despite the contributing concepts and theories evolving over the greater part of the last 200 years, sustainability remains a concept that is difficult to define, whereas identifying what does 
not constitute sustainability is relatively easier. Some of these ideas and concepts are summarised in the chronology inTable 1.

Table 1 Chronology of sustainable development

\begin{tabular}{|c|c|c|c|}
\hline Year & Event & Concepts & Refs \\
\hline $\mathrm{c} 18 \mathrm{oo}$ & $\begin{array}{l}\text { Malthus publishes } \\
\text { Essay on } \\
\text { Population }\end{array}$ & $\begin{array}{l}\text { - Population explosion } \\
\text { - Availability of land } \\
\text { - Sustainability means what } \\
\text { population can be } \\
\text { "sustained" using current } \\
\text { resources }\end{array}$ & {$[3]$} \\
\hline 1962 & $\begin{array}{l}\text { Carson publishes } \\
\text { Silent Spring }\end{array}$ & $\begin{array}{l}\text { - Uncontrolled technology } \\
\text { - Environmentalism } \\
\text { - Environment should not be } \\
\text { compromised for the sake of } \\
\text { unconsidered technological } \\
\text { advancement }\end{array}$ & {$[2-5]$} \\
\hline 1968 & $\begin{array}{l}\text { Ehrlich publishes } \\
\text { The Population } \\
\text { Bomb }\end{array}$ & $\begin{array}{l}\text { - Malthusian concept reborn } \\
\text { - Human impact (I) is } \\
\text { proportional to the } \\
\text { population (P), general } \\
\text { affluence }(\mathrm{A}) \text { and the value } \\
\text { and accessibility to } \\
\text { technology }(\mathrm{T})\end{array}$ & $\begin{array}{l}{[2,3} \\
6-8]\end{array}$ \\
\hline 1972 & $\begin{array}{l}\mathrm{UNCHE}^{* *} \text { in } \\
\text { Stockholm }\end{array}$ & $\begin{array}{l}\text { - Collective responsibility } \\
\text { - Rights and extent of } \\
\text { environmental harm (within } \\
\text { respective jurisdictions) }\end{array}$ & $\begin{array}{l}{[4,12,} \\
13]\end{array}$ \\
\hline 1972 & $\begin{array}{l}\text { Club of Rome } \\
\text { publishes The } \\
\text { Limits to Growth }\end{array}$ & $\begin{array}{l}\text { - } \text { Mesource scarcity } \\
\text { - Modthusian ideas again } \\
\text { consumption show } \\
\text { sustainable development is } \\
\text { impossible, especially with } \\
\text { respect to non-renewable } \\
\text { resources }\end{array}$ & $\begin{array}{l}{\left[3,9^{-}\right.} \\
11]\end{array}$ \\
\hline 1987 & $\begin{array}{l}\text { Brundtland Report, } \\
\text { Our Common } \\
\text { Future, published }\end{array}$ & - Intergenerational equity & $\begin{array}{l}{[2,3,} \\
14]\end{array}$ \\
\hline 1987 & $\begin{array}{l}\text { Montreal Protocol } \\
\text { enacted }\end{array}$ & $\begin{array}{l}\text { - GHG emissions and ozone } \\
\text { layer depletion }\end{array}$ & $\begin{array}{l}{[3,4} \\
15,16]\end{array}$ \\
\hline 1992 & $\begin{array}{l}\text { Earth Summit in } \\
\text { Rio de Janerio }\end{array}$ & $\begin{array}{l}\text { - Polluter Pays Principle } \\
\text { - Precautionary Principle } \\
\text { - Agenda } 21 \\
\text { - Environmental stewardship }\end{array}$ & $\begin{array}{l}{[3,4,} \\
16-18]\end{array}$ \\
\hline 1994 & $\begin{array}{l}\text { Triple Bottom Line } \\
\text { conceived by John } \\
\text { Elkington }\end{array}$ & $\begin{array}{l}\text { - Social, environmental and } \\
\text { economic balance } \\
\text { - Sustainability equities / } \\
\text { capitals / stocks }\end{array}$ & $\begin{array}{l}{[19,} \\
20]\end{array}$ \\
\hline 1996 & $\begin{array}{l}\text { ISO } 14001 \\
\text { established }\end{array}$ & $\begin{array}{l}\text { - Environmental governance } \\
\text { systems } \\
\text { - Corporate integration of } \\
\text { sustainability and } \\
\text { environmental principles }\end{array}$ & $\begin{array}{l}{[4,15,} \\
16]\end{array}$ \\
\hline 2004 & $\begin{array}{l}\text { Five Capitals Model } \\
\text { by Forum for the } \\
\text { Future }\end{array}$ & $\begin{array}{l}\text { - Manufactured, financial, } \\
\text { social, human and natural } \\
\text { capitals } \\
\text { - Hierarchical relationship } \\
\text { between capitals } \\
\text { - Strong sustainability }\end{array}$ & {$[21,22]$} \\
\hline
\end{tabular}

Note: ${ }^{* *}$ United Nations Conference on the Human Environment

\subsection{Hierarchy of sustainability elements}

The elements of sustainability can be organised in a hierarchal fashion as shown inFigure 1, where the direction of the arrow indicates increasing specificity and practical applicability.

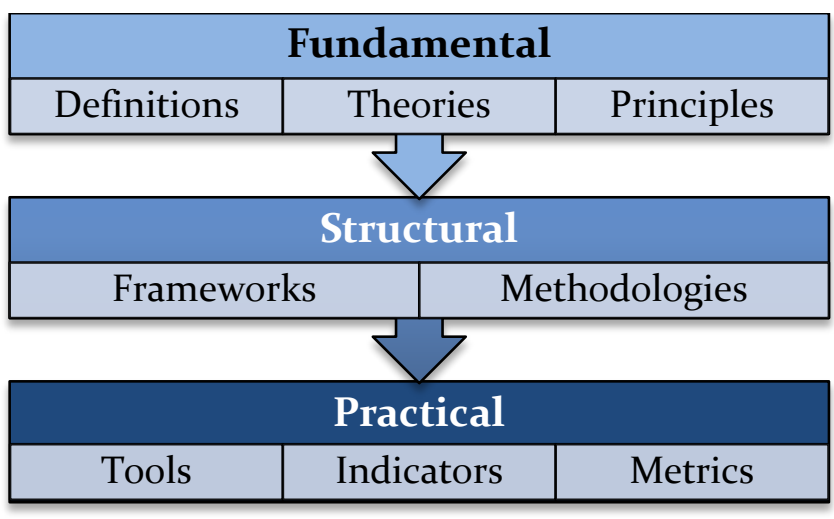

Figure 1 Hierarchy of concepts, defining structures and practical application means of sustainability

There are a multitude of fundamental sustainability principles, theories and definitionsand practically they are applied through frameworks, methodologies and tools. The use of these allows for a better understanding of what sustainability means in practice by translating high level concepts and definitions into practical means of evaluating sustainability. Sustainability evaluations may reveal that a process, action or situation is sustainable or unsustainable, or it may convey a meaning as to "how sustainable" a process, action or situation is.

A sustainability framework is a broad, structured conceptual model which represents a first level translation of sustainability principles and fundamental definitions. Frameworks are similar to an international standard in that they define high level objectives and definitions; however, they are not usually useful for direct application in evaluation. Nevertheless, they are important for defining the boundaries of what is sustainable and what is not sustainable, similar to how a standard defines the generic requirements in order to be compliant with that particular standard.

Practical means of evaluating sustainability are achieved by methodologies. Methodologies are defined sets of actions which allow the evaluation of sustainability against a framework and its protocols. Methodologies are often the basis of sustainability tools, which provide distinct results and are usually specific to a particular application and/or broad interest group (e.g. an industrial sector, an organisation, etc.).

Tools may be comprised of quantitative measures or metrics. Metrics are measureable quantities which may be useful in contributing to evaluating sustainability. The term 'metrics' is frequently interchanged with 'indicators'.

The next section describes the major currently employed sustainability elements.

\section{SustainabilityElements}

\subsection{Sustainability Frameworks}

There are several frameworks available which can be used to define and measure sustainability. A selection of the most prominent frameworks will be reviewed in this section.

\subsubsection{The Natural Step}

Following the UN conference of 1987 and the endorsement of the Brundtland definition of sustainability, Dr Karl-Henrik Robert proposed his idea of a sustainable society which became known as The Natural Step[23]. The Natural Step framework centrally consists of a set of four conditions which describe a sustainable society: "In the sustainable society, nature is not subject to systematically increasing... 
- $\quad$...concentrations of substances extracted from the Earth's crust,

- ...concentrations of substances produced by society,

- ...degradation by physical means;

and, in that society...

- $\quad$...people are not subject to conditions that systematically undermine their capacity to meet their needs" [23, 24].

The last system condition is similar to the Brundtland sustainability definition of societal equity, whilst the first three system conditions are based on the laws of thermodynamics and other fundamental science [24].

The Natural Step provides guidance and boundaries in the sense that it dictates what aspects of life cannot be violated in order to maintain a sustainable society.

One of the more useful cognitive tools provided as part of The Natural Step framework, however, is the backcasting methodology $[23,24]$.Backcasting is the process of placing oneself in the future and imagining that success has been achieved, followed by looking back from the future to the present and asking how that achievement could be attained [23]. Backcasting lends itself as a methodology for long term planning [24] as it promotes a visionary mindset which promotes brainstorming for all conceivable opportunities. The formal steps to the backcasting approach are described in Cook [23] as the approach shown inFigure 2.

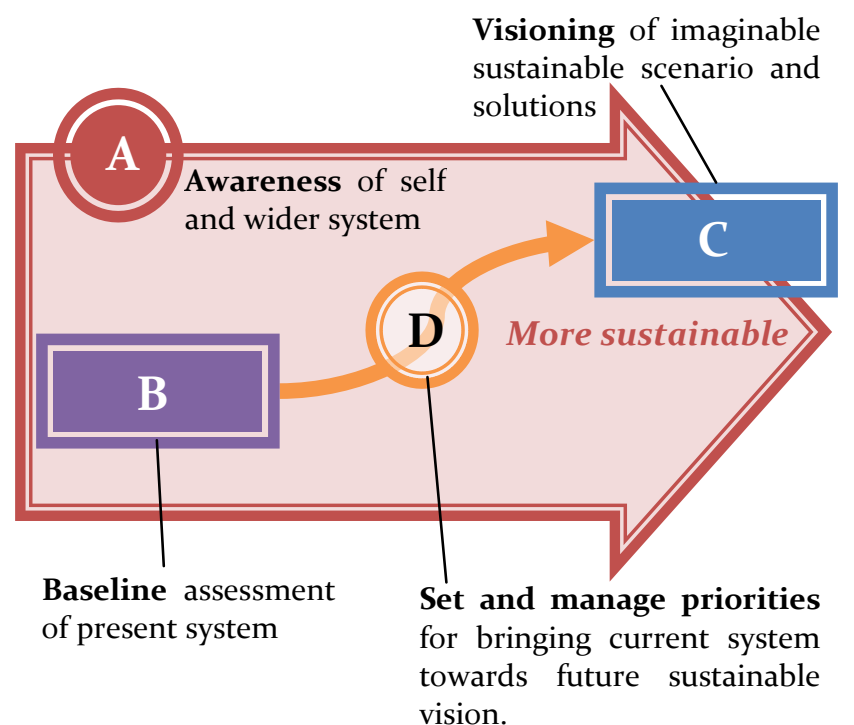

Figure 2 Graphical explanation of backcasting in The Natural Step framework (adapted)[23]

\subsubsection{Triple Bottom Line}

The Triple Bottom Line was coined by John Elkington, and defines the notion of sustainability as the balance of its three constituent equities:

- Economic Equity (or prosperity)

- Environmental Equity

- $\quad$ Social Equity

The first mention of the framework was in a paper by Elkington in 1994 which confirmed that "the concept of sustainable development - involving the integration of environmental thinking into every aspect of social, political and economic activity - has become central to the environmental debate" [19]. However, the message was much clearer in Elkington's 1997 book which stated that "we think in terms of a 'triple bottom line,' focusing on economic prosperity, environmental quality and - the element which business had preferred to overlook - social justice" [20]. The book clearly emphasised that sustainable development clearly advocated a thought process in accounting and decision-making that went beyond relying solely on the traditionally entrenched financial bottom line.

Figure 3shows the connective relationships between each of the three forms of equity covered in the triple bottom line. The regions of intersection between the circles representing the forms of equity reveal more information than that of the previous representations. The intersections represent states which can be classed according to the types of equity represented by the intersecting circles; ultimately, the intersection of all three circles represents the sustainable state, i.e. a balance of all three equities.

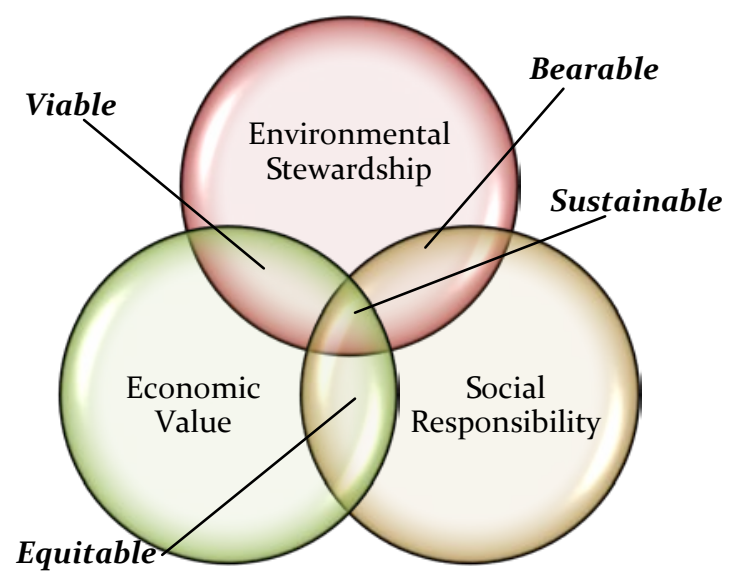

Figure 3 Representation of the triple bottom line equities (adapted) $[\mathbf{2 5}, \mathbf{2 6}$

\subsubsection{Five Capitals Model}

The five capitals model is another equity (or capitals) based framework of sustainability. It was created by the Forum for the Future group and specifically uses the term 'capitals' [27]. In the traditional sense, capital has been thought of in financial or economic terms; the five capitals model emphasises that humans need access to a diverse array of resources if they are to survive and flourish. Porritt states that the five capitals, "when judiciously combined...are the essential ingredients of modern industrial productivity" $[27]$. The five capitals are:

- Human capital

- Social capital

- Built capital (or manufactured or infrastructural capital)

- Natural capital (or environmental or ecological capital)

- $\quad$ Economic capital (or financial capital) [21, 22, 27]

The five capitals are explained in detail inTable 2.The five capitals model is an elaboration of the triple bottom line; in particular, it separates social equity into the capacities of societies and the capacities of humans. Within the triple bottom line framework, the provision for the accounting of technology and infrastructure is unclear or absent; once again, this is more clearly defined in the five capitals model as manufactured capital. As well as this, the five capitals model is defined as a hierarchal model (demonstrated inFigure 4); whereas the triple bottom line can be treated as either hierarchal or parallel. Brereton and Pattenden state that the five capitals model "has strong intellectual pedigree and is influential in the literature on regional and community development" for sustainability[21]. The additional capitals bring with them the need to think creatively about how to measure the different forms of capital and how to assess net impacts within and across capital domains [21]. 
Table 2 Explanation of the five capitals model[22, 27]

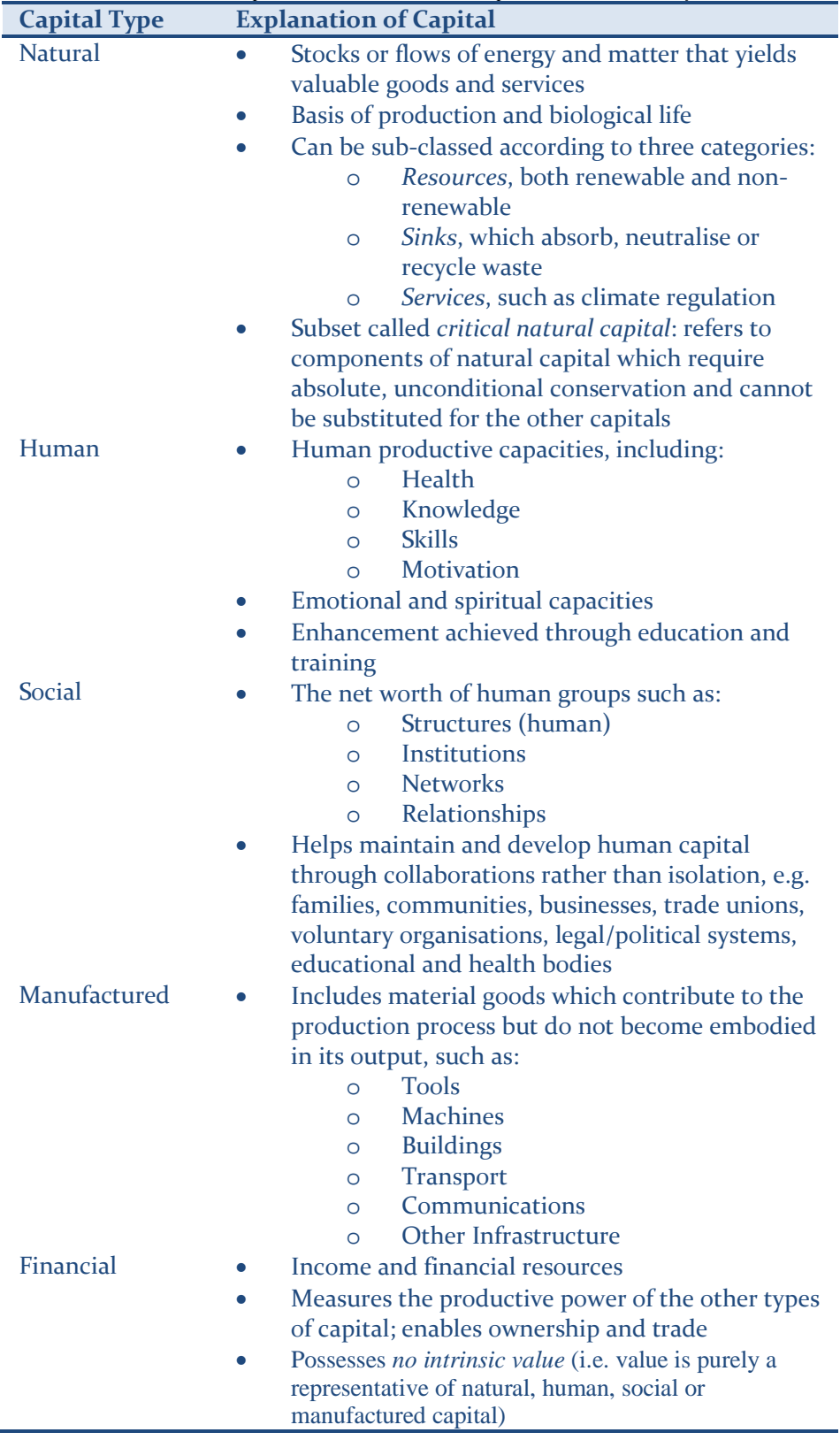

The five capitals model can be graphically represented by the diagram inFigure 4. Natural capital stands as the overarching capital of the others due to its inherent pre-conditionality and underpinning of fundamental human existence [27]. As a consequence, human capital is derived from natural capital as humans exist within the biosphere [27]. Following on, humans have the capacity and the desire to collaborate, hence social capital [27]. The combination of human, social and natural capital is the basis for manufactured and financial capital, i.e. the source and development of modern economies and societies [27].

Using the five capitals model, the Forum for the Future defines sustainability as follows: "Sustainability depends upon maintaining and, where possible, increasing stocks of certain kinds of capital so that we learn to live off the flows (the 'income') without depleting the stock of capital itself; if consumption is at the expense of investment, or results in net capital depletion so that the capital stock declines, then such consumption is not sustainable and will be reduced in the future" [22, 27].

The literature indicates limited uptake or adoption of the five capitals model in specific applications of sustainability frameworks or indicators for projects. The framework has been more useful for evaluating sustainability in more social science contexts; for example, a variation of the framework was proposed as a basis to assess the livelihoods of Latin American rural communities in terms of sustainability and their implications for rural poverty [28].

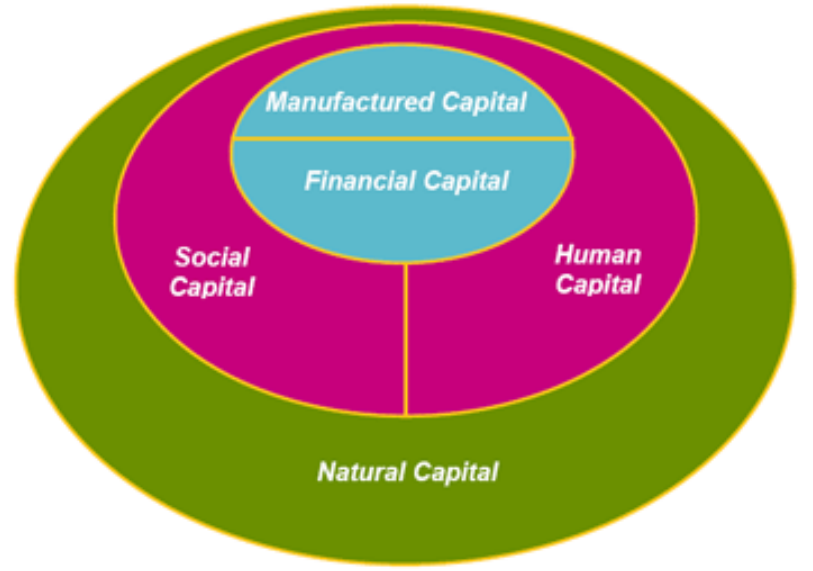

Figure 4 Graphical representation of the five capitals model [22]

\subsubsection{Comparison of The Natural Step, Triple Bottom Line and Five Capitals Frameworks}

The triple bottom line is a simple framework and perhaps this is partly accountable for the potential disadvantages of its use. As demonstrated by three different representations of the same framework, the actual balance and relationships of each of the three "bottom lines" is unclear. Moreover, the framework does not set out to define the "balance" of the three forms of equity which constitutes sustainability, although this can be seen as advantageous since the reductionist view (single indicator) is not necessarily preferable. This ambiguity on the notion of "balance" introduces the complications of strong and weak sustainability.

Strong sustainability implies that all types of equity are mutually exclusive of one another and thus in order to achieve sustainability, the amount of each type of equity can only be either stable or increasing. On the other hand, weak sustainability implies that the three (or five) sets of equity can be exchanged amongst each other; this allows for the growth of one type of equity at the expense of the other one or two types; a usual precondition in the exchange of capitals is that the total equity must remain stable or increase.

The complications of substitutability are compounded due to the inherent difficulty in evaluating what is a fair and equitable exchange between capital types $[15,29]$. The problems of equitable exchange may be mitigated by agreeing on a certain "exchange rate" between capitals [30], however there are no established standards as yet for how this process may take place.

Capital-based frameworks may also lead to the disadvantage of having to consider conflicts and trade-offs between capitals, when the emphasis should be on interconnections and interdependencies as a means for advancing sustainable development [29]. Principles based frameworks, such as The Natural Step, may avoid the difficulties of weak versus strong sustainability. The use of integrated assessment represents a judicious although difficult combination of both approaches [31, 32]. Another idea is to elicit indicators not from a specific capital but rather from the combinationof multiple capitals that provide an indicator of some important element of sustainability [33, 34].

Nevertheless, the triple bottom line remains one of the most common frameworks used in both modern scientific and engineering research [35] as well as globally in policy decisions on sustainability. Carew and Mitchell found that the triple bottom line approach - particularly with respect to the inter-related equity 
model as depicted inFigure 3 - rendered sustainability in the most conceptually accessible manner to engineering academics, allowing them to most clearly understand and contest issues about sustainability (using the framework as a basis)[36].

\subsubsection{Other Frameworks}

There are numerous other frameworks in existence. The rest of this section will discuss a select number of sustainability frameworks in brief detail.

Though focused on the mining and minerals industry, the Mining, Minerals and Sustainable Development (MMSD) project defined sustainable development using the triple bottom line concept plus the additional concept of governance to emphasise the importance of effective decision-making processes and the need for fair, equitable, accountable, transparent and democratic processes[37].

Two frameworks which are based on the triple bottom line and risk include a mathematically-driven, full life cycle, triple bottom line risk framework by Srivasteva and Merz [38], as well as a framework containing a formal risk assessment methodology combined with a list of specific triple bottom line risks [39]. In both frameworks, sustainability is thought of as the process of minimising (or treating) risks which are elicited by considering the threats to the ideal balance of the economic prosperity and social well-being of human societies and the environmental health of the ecosphere. The use of risk (and risk assessment) provides another level of conceptual accessibility, since risk is a well understood concept at all levels of a corporation (i.e. business risk at the corporate level, operational risk at the operational level). However, it should be acknowledged that risk is a difficult metric to aptly and defensibly quantify.

The Sustainable Business Decision Framework, which was developed for the cement industry by the Battelle Memorial Institute, is based on the triple bottom line, but includes an axis of different stakeholder types[40]. The framework (or "value matrix") shows the relevant indicators for sustainability across the dimensions of stakeholder type and equity type. On one dimension - the sustainable equities balance - attention towards proper management of environmental and social equities will result in financial benefits; along the other dimension - the stakeholder type - attention towards proper management of the external stakeholders will result in business strategic benefits that feed back to internal stakeholders (including the company) [40].

One of the weaknesses in the methodology is that there is still a tendency for end-of-pipe sustainability thinking rather than upfront, integrated solutions. The indicator base may not be complete or ideal; however, the framework provides a good basis for characterising the sustainability impacts and benefits of a project by considering the groups of stakeholders that are affected. The framework can be extended along the third dimension of life cycle stage, which introduces additional and more specific sets of indicators [40]. Even though the framework has been developed for the cement industry, the value matrices could be adapted to other applications.

One of the problems with equity based frameworks is that there is no fundamental definition that defines whether a set of equity levels constitutes sustainability or not. The equity based frameworks, such as triple bottom line, are more commonly used to assess sustainability by setting an arbitrary datum (i.e. a time or event) and evaluating the change in equities from that moment. An effort to resolve this deficiency and address the issue of sustainability from a more anthropological point of view has been discussed in a framework which is based on "sustainability quotients" and a "social footprint" [41]. In this study, the five capitals model is reorganised into two ratios: one quotient which is based on natural (ecological) capital, and the other which is based on anthropological (anthro) capital, with the latter being a conglomeration the human, social and constructed capitals [41]. The basis of the ratios is the carrying capacity of each type of capital, which may be dynamic and are interpreted in different ways. Figure 5 shows the definition of the two ratios.

In the context of corporate sustainability management, a corporation is sustainable if it only consumes up to its share of natural resources (i.e. works within the constraints of the environment which is also being consumed in tandem with other corporations) and produces an equal or greater amount of anthro capital than what it is expected to achieve (i.e. does not "overdraw" on the direct human needs but instead produces more equity to meet further human needs) [41].

The sustainability quotients framework also introduces the concept of a binary goal orientation of sustainability. The binary orientation is similar to an absolute orientation, except that the former concept rejects the notion that a state can be more or less sustainable without being entirely sustainable or unsustainable in the first place[41]. Figure 6compares the three different orientations.

Although McElroy et al. are not specific on how the quotients can be defensibly measured (in particular, how the proportional shares of natural and anthro capital can be allocated to organisations and how the process can be defended as equitable)[41], one of the major features the framework provides is a method of determining whether a state is wholly sustainable or not based on a fairly strong, defensible datum (i.e. carrying capacity).

\begin{tabular}{|c|c|c|}
\hline \multirow{2}{*}{$\begin{array}{l}\text { Natural } \\
\text { Sustainability } \\
\text { Performance } \\
\text { Score }\left(S_{N}\right)\end{array}$} & \multirow{2}{*}{$=$} & $\begin{array}{c}\text { Net Rate of Natural Capital } \\
\text { Consumed from Organisational } \\
\text { Operations }\end{array}$ \\
\hline & & $\begin{array}{c}\text { Proportional Share of Rate of } \\
\text { Supply of Natural Capital } \\
\text { Carrying Capacity }\end{array}$ \\
\hline \multirow{2}{*}{$\begin{array}{l}\text { Anthro } \\
\text { Sustainability } \\
\text { Performance } \\
\text { Score }\left(\boldsymbol{S}_{\boldsymbol{A}}\right)\end{array}$} & \multirow{2}{*}{$=$} & $\begin{array}{c}\text { Net Rate of Anthro Capital } \\
\text { Produced from Organisational } \\
\text { Operations }\end{array}$ \\
\hline & & $\begin{array}{c}\text { Proportionate Share of Rate of } \\
\text { Required Production of Anthro } \\
\text { Capital Carrying Capacity }\end{array}$ \\
\hline \multicolumn{3}{|c|}{ Sustainable only if $S_{N} \leq 1$ and $S_{A} \geq 1$} \\
\hline
\end{tabular}

Figure 5 Definitions of Sustainability Quotients for Natural and Anthro Capitals [41]

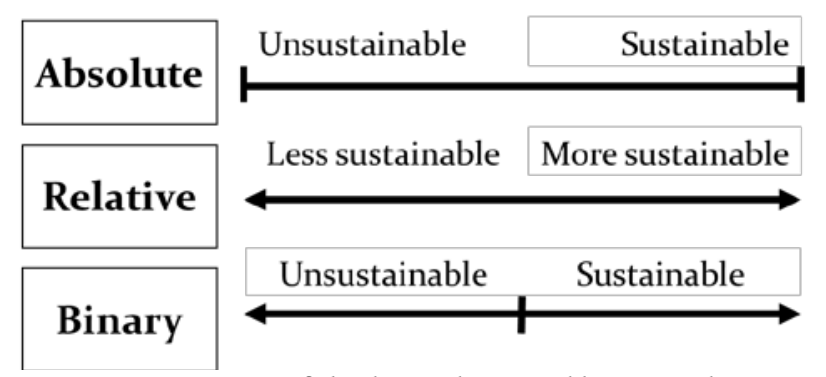

Figure 6 Comparison of absolute, relative and binary goal orientations for sustainability (adapted) [41] 


\subsection{Tools and Methodologies}

Frameworks provide useful conceptual structures from which to base practical means of determining, rating or otherwise assessing sustainability; practical outputs and applications of sustainability principles are achieved through tools and methodologies. Tools and methodologies are therefore the second level of the hierarchy.

The two terms - tool and methodology - are frequently used interchangeably. Some tools and methodologies have been developed into computer software applications. Tools used for the purpose of enforcing a process (e.g. for legislative compliance) may be referred to as 'instruments'.

Many specific sustainability tools and methodologies exist however, this section will discuss the two most important and widely applied tools that have formed the basis of many other constructed sustainability tools.

\subsubsection{Environmental Impact Assessment}

Environmental Impact Assessment (EIA) can be described as "the process of identifying, predicting, evaluating and mitigating the biophysical, social and other relevant effects of development proposals prior to major decisions being taken and commitments made" [42].

EIA is one of the first instruments utilised to assess a potential project for environmental impacts. In general, the EIA process is followed as a standard requirement for large projects that are likely to cause significant impact to the environment; the requirements for EIAs and their component processes may be described in legislation at all levels of government.

The EIA process involves the identification of all potential environmental (and social impacts) and relevant mitigation measures required to control those impacts. A risk assessment process is usually utilised, which also involves formal risk quantification processes and impact modelling in order to strongly demonstrate the extent of impacts before and after proposed mitigation measures.

The biggest weakness of an EIA processis that there are generally only provisions for legislative compliance and not necessarily that of continuous improvement or even a holistic approach to sustainable operation. There is evidence to support that the current process as it stands is weak in achieving the goals of environmental and biodiversity protection [43-45]. Despite the deficiencies of the EIA process, it is a necessary but insufficient step towards ensuring a commitment towards sustainable development; certainly, the effective execution of an EIA on the part of the proponent can lead to a higher propensity of acceptance of the project both legally and socially [46], but further progress towards sustainable development relies on companies going beyond the minimal compliance level and utilising additional tools.

\subsubsection{Life Cycle Assessment}

Life Cycle Assessment (LCA) is a technique used to compare the (primarily environmental) impacts of a product or process over the entire life cycle; for example, the life cycle of a product encompasses all stages from the collection of the raw materials required to create the product (cradle) through to manufacture, use and finally its disposal (grave). Figure 7illustrates the general life cycle of a product [47].

LCAs are conducted by comparing the environmental burden "inventories" across the life cycles of alternative processes or products. The steps involved in conducting an LCA study have been standardised in the ISO 14040 series $[48,49]$.

LCA promotes holistic systems thinking, and is a useful for strategically pinpointing the stages in a production process which have the most significant environmental impacts [50]. Most sustainability analyses and tools stem from some of the techniques and concepts embodied by LCA - particularly the concept of life cycle thinking.

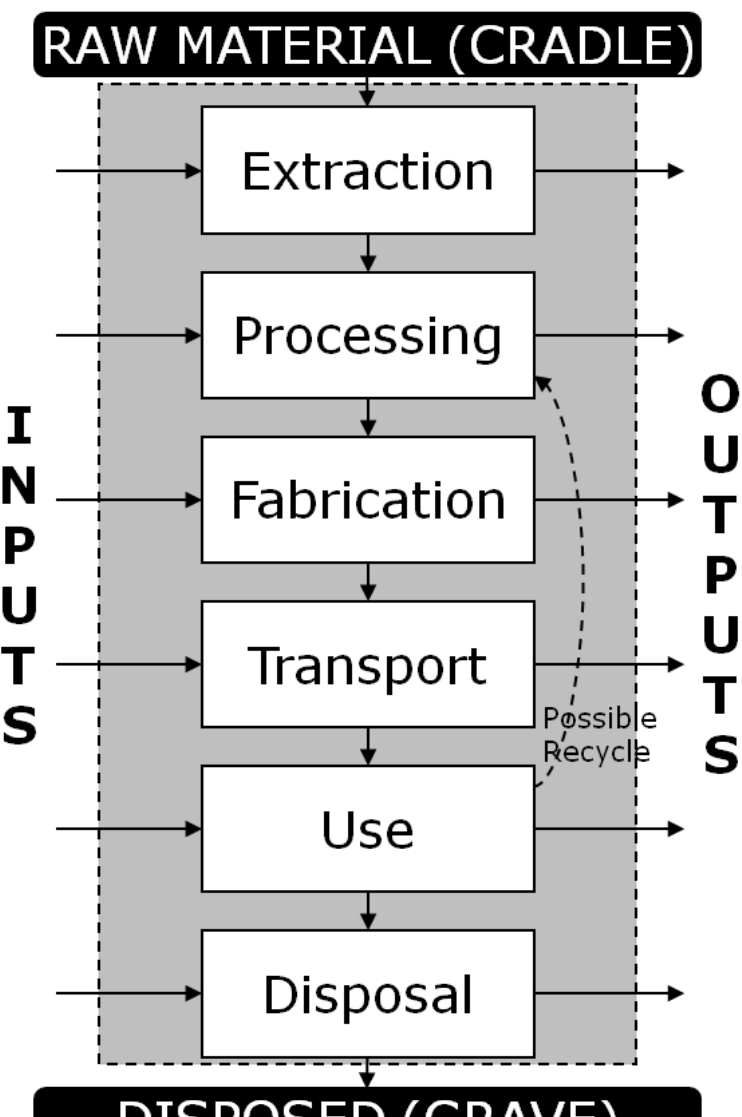

\section{DISPOSED (GRAVE)}

Figure 7 Generic life cycle of a product [47]

Despite the widespread recognition of LCA, it is important to acknowledge its limitations. LCAs typically only assess environmental burdens, thus they cannot be used as the sole tools for decision-making processes; indeed, LCAs are typically used in conjunction with social impact studies and full life cycle costing (or other economic assessment) in decision-making processes, although there has been research into investigating how social indicators may be able to be quantified and hence integrated as part of the life cycle inventory [51]. LCAs are spatially and temporally limited, in that the basis chosen for a particular LCA study only takes into account impacts at a specific time (or set of conditions) for a certain general location, although some work has been done towards incorporating these aspects [52]. Full LCA studies are also generally time-consuming and complex.

\subsection{Metrics and Indicators}

Metrics and indicators represent the basic building blocks of measurement tools and methodologies in sustainability assessment. The two words are typically interchangeable. Metrics provide the basis for quantitative sustainability measurement and assessment, which is most useful to the engineering and scientific fields, particularly where metrics in sustainability assessment can be linked to traditional and emerging engineering tools such as simulators and life cycle assessment. Metrics also provide useful measures that can be integrated into accounting and risk assessment.

The bases of many sets of metrics draw upon the key elements of frameworks and the embodied concepts with the frameworks; for example, the extensive sets of metrics which are based on the triple bottom line contain measures which would either enhance 
or diminish stocks of economic, environmental or social equity. Metrics are then selected and refined based on the application required, the process being evaluated and what can be conceivably measured.

Most often, sustainability metrics are created using a top-down approach, whereby metrics are selected to fit a sustainability framework. A bottom-up approach for creating metrics (i.e. through stakeholder engagement) is possible, but care needs to be taken to ensure that metrics are relevant to sustainability performance; in particular, multi-stakeholder engagement and approaches to identify appropriate indicators for measuring sustainability are crucial to a defensible analysis[53, 54].Moreover, as many sustainability metrics are developed for general applicability, they tend to lack a connection to the local context, which is ultimately essential for knowing the real impact of an operation or process [55]. Ultimately, a combined approach is advisable, ensuring adherence to fundamental sustainability principles but at the same time ensuring practicality and applicability for the task at hand.

The selection of indicators is important, as rigorous processes are required to avoid irrelevancy - hence a variety of guidelines have been produced [56]. Belton and Stewart give eight guidelines for selecting indicators as a result of considering the value of the issues for the task at hand:

(a) value relevance;

(b) understandability;

(c) measurability;

(d) non-redundancy;

(e) judgmental independence;

(f) balance of completeness and conciseness;

(g) operationability; and

(h) simplicity versus complexity[57].

These guidelines should be adhered to as closely as possible in order to ensure effective use of indicators in multi-criteria decision analysis [58].

\subsubsection{The Global Reporting Initiative}

Of all the indicator systems in the world, the Global Reporting Initiative (GRI) is the most extensive and widely subscribed to. First established in 1997 by the non-profit group CERES, the GRI has grown to be a multi-sectoral set of indicators to measure economic, environmental and social performance. The GRI was initially created to promote a unified, transparent, reliable and complete method of reporting for sustainability. The use of the GRI is governed by the G3 Reporting Framework[59], which consists of the following components:

- $\quad$ Principles and Guidance: contains the overarching guidelines for using the GRI and how to write an effective sustainability report.The principles are used to test and elicit what needs to be reported as well as a means of testing how well it has been reported.

- Protocols: are the actual indicators to be reported on and their definitions (this is to assist in avoiding any ambiguities)

- Reporting Details, which comprise of three sub-sections:

o Standard Disclosures: are the bare minimum set of indicators that every GRI subscribed report must include and be reported.

o Sector Supplements: provide additional sets of indicators dependent on industry type.

o National Annexes: are further sets of indicators that are specific to particular nations.

The GRI is composed of both quantitative and qualitative indicators. From the standard disclosures alone, there are 110 indicators in all: 39 environmental, 56 social and 15 economic. The vast number of indicators and the effort required to collect and/or monitor all the data required for them precludes the use of the full GRI set for almost any day-to-day operational purpose, however it is more commonto only select specific indicators from the GRI set; the selection of indicators is based on those that are of interest to the task at hand and which display the most variation between different scenarios. The GRI indicators have also been shown to be largely available from legislated reporting requirements especially the environmental indicators - which may lead to some streamlining of their derivation [6o].

\subsubsection{Ecological Footprint}

The ecological footprint is both a framework and an aggregate measurement developed in 1990 by Mathis Wackernagel and William Rees at the University of British Columbia [61]. Ecological footprint is defined as the area of biologically productive (or bioproductive) land and water needed to produce required resources and assimilate generated wastesusing prevailing technology $[61,62]$. Ecological footprint may be measured as the total bioproductive area required for human activity and its associated impacts; when used for socio-economic purposes and policy making, it is often stated in terms of area per capita.

Ecological footprint is commonly interpreted as a metric, however it also lends itself as a framework as it describes a paradigm that the global demands (through consuming resources and generating wastes) can be attributed to the services of the biosphere, namely through the land and the sea; as a corollary, the extent of the services offered by bioproductive land can be quantified. This latter fact is an advantage (i.e. provides a central, unified measure across several types of indicators in order to allow for objective judgements between different footprint measures) as much as it is also a drawback: the ecological footprint is figured on the assumption that the earth provides an equal - albeit averaged - bioproductivity for every unit area available, which is not the case. As well as this, the ecological footprint being a single indicator does not give insight into what the individual impacts are [35]. The ecological footprint must be interpreted for what it is: it is a measure of the demand of biosphere services and thus it is principally an environmental indicator/measure; the economic and social indicators are precluded [41].

Ecological footprint vastly reduces the complexity of human impacts on nature (to appropriated biomass) and thus only offers a partial assessment of global sustainability [62]. These deficiencies, however, have not stopped the ecological footprint from becoming one of the most common measures of sustainability today. The simplicity of a single measure has possibly encouraged its use in policy decision-making in several levels of government around the world [61], particularly in driving the environmental agenda.

\section{Discussion}

A corollary of the multi-faceted nature of sustainability is that there are a large number of frameworks, indicators and metrics along with supporting and implementing tools - that are available for guiding and assessing for sustainability. However, the ability to make decisions based on the outputs of such tools and indicators is limited when they are used in isolation due to hidden assumptions. To this extent, it is necessary to select the correct indicators or tools for the correct application, which may involve a conceptual compromise, i.e. to accept the "incompleteness" of an assessment based on the selection of tools or methodologies that will still fulfil the primary purpose of why the assessment is being conducted.

The publicly available literature shows a high degree of adoption of sustainability at the corporate level; however, the degree of integration of sustainability at an operational / practical level is still limited. Moreover, although studies do exist where 
operations are starting to integrate common indicators like energy usage, water usage and carbon dioxide emissions, it is now more important to adopt a more holistic view of sustainability by targeting

(a) a greater range of sustainability indicators, such as minor and fugitive elements,

(b) the consideration of various levels of the production cycle in order to better understand the origin and effects of sustainability impacts and benefits, and

(c) a structured process by which to establish, characterise and understand such sustainability impacts and benefits in order to better utilise them in day-to-day decisionmaking processes.

The GRI provides a comprehensive reporting platform and an extensive suite of indicators that could be suitable to measure at an operational level; however, the effort required to conduct a GRI-like analysis on a day-to-day operation would be significant.

\section{Conclusions}

This review has demonstrated that the development of the theories and concepts of sustainability are relatively mature, however due to the multi-faceted nature of sustainability, it is a difficult concept to apply successfully, especially when the application moves away from a policy-oriented one to a technically-oriented one.

In general, for researchers across a variety of fields, and for practitioners based in real business or industrial operations who wish to analyse or incorporate sustainability in their work, it is important to consider whether the framework, indicators and tools that they are applying reflect a broader and deeper understanding of sustainability. Many efforts in engaging with sustainability only focus on a single element - such as the environmental impact - disregarding the other elements which are almost universally considered to be important (at least the economy and society). Likewise, there is a tendency in research to utilise a top-down approach that does not integrate the preferences or priorities of the community, thus limiting the ability to communicate the message or benefits of a technology, policy or operation.

\section{Acknowledgements}

The work in this article forms part of a $\mathrm{PhD}$ project which was supported by funding from The University of Queensland and the Co-operative Research Centre for Sustainable Resource Processing.

\section{References}

[1] Tuazon, D, Corder, G, Powell, M, and Ziemski, M, A practical and rigorous approach for the integration of sustainability principles into the decision-making processes at minerals processing operations.Minerals Engineering, 2012. 29(o): p. 65-71.

[2] Mulder, K, ed. Sustainable Development for Engineers: A Handbook and Resource Guide. 2006, Greenleaf Publishing: Oxford.

[3] Dresner, S, The Principles of Sustainability. 2006, London: Earthscan Publications.

[4] Baylis, J, Smith, S, and Owens, P, The Globalisation of World Politics: An introduction to international relations. 4 ed. 2008, New York: Oxford University Press.

[5] Ward, B and Dubos, R, Only One Earth: The Care and Maintenance of a Small Planet. 1972, New York: W. W. Norton \& Company.
[6] Chertow, MR, The IPAT Equation and Its Variants.Journal of Industrial Ecology, 2001. 4(4): p. 13-29.

[7] Ehrlich, PR, The Population Bomb. revised ed. 1971, New York: Ballantine Books.

[8] Maddox, J, The Doomsday Syndrome. 1972, London: Macmillan.

[9] Meadows, D, Randers, J, and Meadows, D, Limits to Growth: the 30year update. 2004, White River Junction: Chelsea Green Publishing.

[10] Meadows, DH, Meadows, DL, and Randers, J, Beyond the Limits. 1992, London: Earthscan.

[11] Meadows, DH, Meadows, DL, Randers, J, and Behrens, WW, The Limits to Growth. 1974, London: Pan Books.

[12] Elliott, JA, An Introduction to Sustainable Development. 3rd ed. Routledge Perspectives on Development. 2006, London: Routledge.

[13] UNEP. Declaration of the United Nations Conference on the Human Environment, http://www.unep.org/Documents.Multilingual/Default.asp?Docume ntID=97\&ArticleID=1503. Accessed 24 March 2009.

[14] Brundtland, GH and WCED, Our Common Future. 1987: Oxford.

[15] Dalal-Clayton, B and Bass, S, eds. Sustainable Development Strategies: A Resource Book. 2002, Earthscan: London.

[16] Munasinghe, M and Swart, R, Primer on Climate Change and Sustainable Development: Facts, Policy Analysis and Applications. 2005, Cambridge: Cambridge University Press.

[17] UN. Annex I: Rio Declaration on Environment and Development [A/CONF.151/26 (Vol. I)]. in United Nations Conference on Environment and Development. 1992a. Rio de Janerio: United Nations.

[18] UN. Agenda 21, 1992b. http://www.un.org/esa/sustdev/documents/agenda21/english/agend a21toc.htm. Accessed 200924 April.

[19] Elkington, J, Towards the Sustainable Corporation: Win-Win-Win Business Strategies for Sustainable Development.California Management Review, 1994. 36(2): p. 90-100.

[20] Elkington, J, Cannibals with Forks: The Triple Bottom Line of 21st Century Business. 1997, Oxford: Capstone.

[21] Brereton, D and Pattenden, C, Measuring what matters: Monitoring the contribution of a new mining project to community sustainability, in 3 rd International Conference on Sustainable Development Indicators in the Minerals Industry. 2007: Milos Island, Greece.

[22] Forum for the Future. The Five Capitals model, 2005. http://www.forumforthefuture.org/our-approach/tools-andmethodologies/5capitals. Accessed 6 April 2009.

[23] Cook, D, The Natural Step: Towards a Sustainable Society. Schumacher Briefings, ed. Society, TS. 2004, Devon: Green Books.

[24] Holmberg, J and Robert, K-H, Backcasting from non-overlapping sustainability principles - a framework for strategic planning.International Journal of Sustainable Development and World Ecology, 2000. 7: p. 291-308.

[25] Great Britain Forestry Commission. Sustainability, 2004 http://www.forestry.gov.uk/forestry/edik-59fmzf. Accessed 7 April 2009.

[26] Mitchell, CA, Carew, AL, and Clift, R, The Role of the Professional Engineer and Scientist in Sustainable Development, in Sustainable Development in Practice: Case Studies for Engineers and Scientists, Azapagic, A, Perdan, S, and Clift, R, Editors. 2004, John Wiley \& Sons: West Sussex. p. 29-55.

[27] Porritt, J, Capitalism as if the world matters. 2005, London: Earthscan.

[28] Bebbington, A, Capitals and Capabilities: A Framework for Analysing Peasant Viability, Rural Livelihoods and Poverty.World Development, 1999. 27(12): p. 2021-2044.

[29] Pope, J, Annandale, D, and Morrison-Saunders, A, Conceptualising sustainability assessment.Environmental Impact Assessment Review, 2004. 24: p. 595-616.

[30] Serageldin, I and Steer, A, eds. Making Development Sustainable: From Concepts to Action. Environmentally Sustainable Development Occasional Paper Series No. 2, ed. The World Bank. 1994, The World Bank: Washington D.C.

[31] Gibson, RB, Sustainability assessment: basic components of a practical approach.Impact Assessment and Project Appraisal, 2006c. 24(3): p. 170-182.

[32] Gibson, RB, Beyond the pillars: sustainability assessment as a framework for effective integration of social, economic and 
ecological considerations in significant decision-making.Journal of Environmental Assessment Policy and Management, 2006a. 8(3): p. 259-280.

[33] Morrison-Saunders, A and Therivel, R, Sustainability integration and assessment.Journal of Environmental Assessment Policy and Management, 2006. 8(3): p. 281-298.

[34] Azapagic, A, Developing a framework for sustainable development indicators for the mining and minerals industry.Journal of Cleaner Production, 2003. 12(2004): p. 639-662.

[35] McLellan, BC, Location-Specific Sustainability Metrics for Hydrogen Energy Systems, in Chemical Engineering. 2006, The University of Queensland: Brisbane.

[36] Carew, AL and Mitchell, CA, Teaching sustainability as a contested concept: capitalising on variation in engineering educators' conceptions of environmental, social and economic sustainability.Journal of Cleaner Production, 2006. 16: p. 105-115.

[37] MMSD, Mining and Minerals Sustainability Survey, Coopers, PW, Editor. 2001, MMSD: London. p. 37 pages.

[38] Srivastava, K and Merz, R, Mathematics of triple-bottom line risks in water infrastructure projects, in The Environmental Engineer. 2008, Society of Sustainability and Environmental Engineering: Barton. p. 9-11.

[39] Evans, R, Brereton, D, and Joy, J, Risk assessment as a tool to explore sustainable development issues: lessons from the Australian coal industry.International Journal of Risk Assessment and Management, 2007. 7(5): p. 607-619.

[40] Fiksel, DG, Garvin, L, and Brunetti, T, Substudy 3: Business Case Development, in Toward a Sustainble Cement Industry, World Business Council for Sustainable Development, Editor. 2002, Battelle Memorial Institute.

[41] McElroy, MW, Jorna, RJ, and van Engelen, J, Sustainability Quotients and the Social Footprint.Corporate Social Responsibility and Environmental Management, 2008. 15: p. 223-234.

[42] International Association for Impact Assessment, Principles of Environmental Impact Assessment Best Practice. 1999: Fargo.

[43] Buckley, R, How well does the EIA process protect biodiversity?, in Conserving biodiversity: threats and solutions, Bradstock, RA, et al., Editors. 1995, Surrey Beatty \& Sons.

[44] Macintosh, A, Why the Environment Protection and Biodiversity Conservation Act's referral, assessment and approval process is failing to achieve its environmental objectives.Environmental and Planning Law Journal, 2004. 21(4): p. 288-311.

[45] Hughes, L, Environmental Impact Assessment in the Environment Protection and Biodiversity Act 1999 (Cth).Environmental and Planning Law Journal, 1999. 16(5): p. 441-467.

[46] Gibson, RB, Sustainability assessment and conflict resolution: Reaching agreement to proceed with the Voisey's Bay nickel mine.Journal of Cleaner Production, 2006b. 14: p. 334-348.

[47] Tuazon, D and Corder, GD, Life cycle assessment of seawater neutralised red mud for treatment of acid mine drainage.Resources, Conservation and Recycling, 2008. 52(11): p. 1307-1314.

[48] Standards Australia, ed. AS/NZS ISO 14040:1998: Environmental management - Life cycle assessment - Principles and framework. Australian/New Zealand Standards, ed. Standards Australia. 1998, Standards Australia: Homebush.

[49] Standards Australia, ed. AS/NZS ISO 14041:1999: Environmental management - Life cycle assessment - Goal and scope definition. Australia/New Zealand Standards, ed. Standards Australia. 1999, Standards Australia: Homebush.

[50] Norgate, TE, Jahanshahi, S, and Rankin, WJ, Assessing the environmental impact of metal production processes.Journal of Cleaner Production, 2006. 15: p. 838-848.

[51] Labuschagne, C and Brent, AC, Social Indicators for Sustainable Project and Technology Life Cycle Management in the Process Industry.International Journal of Life Cycle Assessment, 2006. 11(1): p. 3-15.

[52] Chan, AW and Minns, DE. Extending LCA for assessing sustainability. in Third Australian LCA Conference. 2002. Gold Coast.

[53] Basu, AJ and Kumar, U, Innovation and Technology Driven Sustainability Performance Managment Framework (ITSPM) for the Mining and Minerals Sector.International Journal of Surface Mining, Reclamation and Environment, 2004. 18(2): p. 135-149.
[54] Warhurst, A, Sustainability Indicators and Sustainability Performance Management. 2002, World Business Council for Sustainable Development.

[55] McLellan, BC, Diniz Da Costa, JC, and Dicks, AL, Location-specific sustainability metrics: Measuring sustainability space.Sansai, 2012. 6 : p. 18.

[56] Bossel, H, Indicators for sustainable development: theory, method, applications. 1999, International Institute for Sustainable Development (IISD): Winnipeg.

[57] Belton, V and Stewart, T, Multiple criteria decision analysis: an integrated approach. 2002, Kluwer Academic: Dordrecht.

[58] Azapagic, A and Perdan, S, An integrated sustainability decisionsupport framework: Part I: Problem structuring.International Journal of Sustainable Development and World Ecology, 2005. 12: p. 98-111.

[59] GRI, Sustainability Reporting Guidelines, GRI, Editor. 2006, Global Reporting Initiative: Amsterdam, Netherlands.

[6o] McLellan, BC, Streamlining the use of legislated reporting to move to "Life of project" sustainability reporting.International Journal of Mining and Mineral Engineering, 2013. (article in press).

[61] Global Footprint Network. Ecological Footprint - Ecological Sustainability, http://www.footprintnetwork.org/en/index.php/GFN/. Accessed 16 Feb 2009.

[62] Wackernagel, M, et al., Tracking the ecological overshoot of the human economy.Proceedings of the National Academy of Sciences, 2002. 99(14): p. 9266-9271. 